Article

\title{
Effects of High-Tech Urban Agriculture on Cooking and Eating in Dutch Nursing Homes
}

\author{
Paulien C. H. van de Vlasakker *(i) and Esther J. Veen $($ ) \\ Department of Social Sciences, Rural Sociology Group, P.O. Box 8130, 6700 EW Wageningen, The Netherlands; \\ esther.veen@wur.nl \\ * Correspondence: paulien.van.de.vlasakker@liu.se
}

Received: 23 May 2020; Accepted: 2 July 2020; Published: 3 July 2020

\begin{abstract}
Questions have arisen about the sustainability of the industrialised food system. Alternatives like urban agriculture have emerged to reduce the negative social, environmental and health impacts of industrial agriculture. Such new food supply chains can change the way that people acquire and process food. This study looks at high-tech indoor gardening practices in nursing homes for elderly people, studying four nursing homes in the Dutch city of Velp. We used both qualitative and quantitative approaches to collect data, using site visits, a survey amongst employees, and semi-structured interviewees with residents and decision makers. Inspired by social practice theory, we aimed to understand the transformation of existing practices, investigating how the gardens affect cooking and eating practices, and how their constitutive elements of meaning, material and competences enable these transformations. Our work shows that the indoor gardens resulted in an integration of gardening and the resulting harvest into cooking practices, which in turn transformed residents' eating practices. Appreciation of the taste of fresh vegetables and appearance of the meal decorated by fresh vegetables, as well as observing the growth of plants and their use, holds value for the elderly residents. Employees welcome the possibility to serve healthier meals. The integration of indoor gardens in existing cooking practices is more successful when employees have gardening and/or cooking competences, when they enjoy cooking and when they do not already cook with fresh ingredients. The gardens are more easily integrated when they are easily accessible. The materiality of the gardens does not require fully equipped kitchens.
\end{abstract}

Keywords: urban agriculture; cooking practices; nursing homes; social practice theory; high-tech indoor gardens

\section{Introduction}

The number of Dutch people over eighty years old is expected to grow from 0.8 million now to 1.2 million in 2030 [1]. More than fifteen percent of elderly people of 75 years or older live in a residential institution for long-term care [2]. In addition to the current challenges of nursing homes to provide their residents with proper care, the Dutch government expects an increase in the needs of these vulnerable elderly [3]. To optimize current care and prepare the nursing care sector for the future and its challenges, the Dutch Ministry of Health, Welfare and Sport has set a number of objectives, one of which is to improve the living and wellbeing of elderly people living in nursing homes [4].

An important part of wellbeing is good food and healthy eating. A healthy diet makes a noticeable difference in the quality of life [5]. Different studies have shown that malnutrition is a common problem among elderly people living in nursing homes [6]. Insufficient vegetable intake increases the risk of malnutrition $[7,8]$. The specific characteristics of the elderly need to be taken into account to stimulate vegetable intake and help prevent malnutrition [8]. Often, elderly people do not eat enough vegetables because of a lack of appetite and difficulties with chewing and swallowing [5]. 
This requires personalised vegetable servings that are, for example, cut and peeled. Freshness is also an important factor for increasing the intake of vegetables: fresh vegetables offer added value because of their taste [8].

A recent niche development entering nursing homes is the high-tech indoor garden [9]. High-tech indoor gardens are a specific, smaller-scale, form of high-tech urban agriculture, in itself a relatively new phenomenon. High-tech urban agriculture uses advanced technologies, such as LED lighting and hydroponic cultivation methods, which allow the production of fresh vegetables and herbs inside the built-up environment. Due to the completely controlled environment of the growing systems neither sunlight nor soil is needed. The advantages of high-tech urban agriculture lie in the efficiency of food production, but also in its continuity (which also contributes to its efficiency): where conventional urban farming or gardening initiatives fall silent during autumn and winter months, high-tech urban agriculture practices continue throughout the year. Furthermore, hydroponic cultivation can reduce the use of pesticides by a hundred percent, due to the clean cultivation methods (no soil and manure) and the fact that the growth of plants often takes place within a closed environment to which insects have no access $[10,11]$.

Besides these advantages in terms of efficiency, continuity and limited pesticide-use, high-tech indoor gardens can also function as a form of 'indoor greening' in nursing homes. Indoor greening contributes to the perceived environmental ambiance of a room [12-14] as natural elements in the built healthcare environment reduce feelings of stress [15]. Indoor plants can also improve climate [16] and air quality [17]: they balance the humidity of the air, clean the air and create a comfortable environment in nursing home settings by removing harmful substances, such as from urine losses and chemical detergents $[18,19]$. Furthermore, indoor gardens can enhance the lighting of a location and improve the aesthetics of the indoor space [20]. Different studies therefore confirm that (vegetable) gardens in health care settings can improve health, wellbeing and life-satisfaction [21-24].

Finally, by growing vegetables inside nursing homes, high-tech indoor gardens lead to the availability of fresh vegetables, representing an extremely short production-to-consumption path. Without having to undergo any packaging or distribution processes, vegetables can be consumed as soon as they are harvested. These gardens thus enable the use of fresh and local vegetables, and in contrast to outdoor gardens, high-tech indoor gardens can offer advantages such as the all-year-round production of leafy greens $[20,25]$. Local vegetables, grown close to- or as in this case: inside-the nursing home, may also help improve the food intake among elderly in care institutions by contributing to the experience of the meal [8]. For all these reasons we may expect high-tech indoor gardens to influence diets of elderly living in nursing homes. However, to the best of our knowledge this has not yet been studied. The aim of this paper, therefore, is to explore to what extent high-tech indoor gardens may influence cooking and eating practices in nursing homes, and what is needed to enable such changes.

The rest of this paper is organized as follows: The next section explains our theoretical starting point, inspired by practice theory, elaborates on the cases studied and explains the methods for data collection. Thereafter, we analyse how the practices of cooking and eating are influenced by the high-tech indoor gardens, showing differences between the four nursing homes studied and their characteristics. In the discussion, we elaborate on meaning, material and competence, the constitutive elements of practices, and investigate how these enable the integration of the gardens in cooking practices. We end our paper with some conclusions.

\section{Materials and Methods}

\subsection{Social Practice Theory}

The theoretical starting point of this paper is inspired by Social Practice Theory (SPT). Stemming from the work of Bourdieu [26-28] and the structuration theory of Giddens [29], SPT has recently received renewed attention [30]. The main premise on which SPT is based is that people routinely 
participate in practices. A practice can be considered as concrete human activity, or what people actually do. The definition as proposed by Reckwitz [31] is arguably the most cited: Reckwitz sees a practice as "a routinised type of behaviour which consists of several elements, interconnected with one other-forms of bodily activities, forms of mental activities, 'things' and their use, a background knowledge in the form of understanding, know-how, states of emotion and motivational knowledge" (p.249).

People are the carriers of practices. By performing practices, they actualise and sustain them, so that the performance of practices creates routinised forms of behaviour [31] and, in turn, a routinisation of daily life. The structural characteristics of a social system are therefore both the outcome of and the medium for practices: practices enable individual actions-people choose which practices to engage in-and through the performance of these practices social structure is created [29]. In other words, both social order and individuality result from practices [32].

A practice is only reproduced if it finds a place within the rhythm of daily life [33]. This implies that whether or not new practices are taken up and transitioned into routinized behaviour depends on the extent to which people are able to revise the texture and rhythm of their daily lives [34]. Routinisation also means that performance in a familiar practice is often neither fully conscious nor reflective [35]. Much of people's day-to-day behaviour is not directly motivated, but based upon unconscious motivations and practical consciousness [29]. Nonetheless, people are knowledgeable agents [29] who consciously choose which practices to engage in [32]. Practice theory is a useful theoretical starting point for our work because we are interested in understanding to what extent and especially how (indoor) gardening is taken up in nursing homes, and how it is integrated within the yet existing and presumably highly routinised practices of cooking (and eating) in these places.

Shove and Pantzar [36] operationalise practices by defining three constitutive elements: meaning, material and competences. Meaning represents the social and symbolic significance of practices. Material encompasses everything tangible that is needed to carry out the practice, such as objects, tools, infrastructure and the body. Competences involve the knowledge, skills and understanding needed to perform the practice. In this paper, we turn to these three constitutive elements to understand the practices of cooking and eating, and whether and how these accommodate the new element of the indoor garden. Decomposing practices into these three elements enables us to study, in more detail and in a structured way, how practices are shaped and changed in daily life in the nursing homes.

Practices work when the material elements and those of meaning and competence are linked, and transformed through doing practices [33]. In order to understand change, it is useful to study the different elements and the links between them: the emergence and demise of practices relates to the forging and/or failing of links between materials, competences and meaning. New proposals in product or service development, such as high-tech indoor gardens, can only become successful when they become embedded in the details of daily life [33]. As new practices always emerge against the backdrop of previous, related ways of doing [36], new practices have a higher chance of being adopted when they carry elements which are recognizable and familiar (e.g., reference well-known skills and competences, accessible materials, shared meanings). In this paper, we explore how high-tech indoor gardens affect cooking and eating practices in nursing homes by investigating the introduction of new materials (indoor gardens and their harvests), linking these to existing or to-be-developed materials, competences and meanings. We now first clarify what we understand as cooking and eating practices, and how these are potentially affected by indoor gardens.

Cooking in nursing homes can be defined as a variety of tasks that all relate to the preparation of the meal. Hence, it refers to heating, frying or boiling the food, but also to opening prepacked food, reading a recipe, following the instructions of a food expert and serving the meal. When indoor gardens are involved, cooking can also include harvesting: employees harvest from the gardens in order to use the vegetables in their cooking practices. This implies that harvesting is intricately interwoven with cooking practices. Indoor gardens may thus affect cooking practices by adding the task of harvesting to the required repertoire of activities. It is worth mentioning that the employees of 
the nursing homes we studied are not responsible for the maintenance of the gardens; they only need to harvest the crops. Garden maintenance is the responsibility of Vegger, the company that installed the gardens. Furthermore, we did not consider the entire cooking practice in nursing homes, but studied how employees responsible for cooking integrate the indoor garden in their practices.

Cooking practices can influence the vegetable intake by affecting the type and amount of vegetables being served. When employees integrate fresh vegetables and herbs from the garden in their cooking practices, this does not necessarily translate into residents consuming these. In the nursing homes where elderly people with dementia live, there is a high probability that the residents will eat what they are given. If employees use vegetables and herbs from the garden in the preparation of the meals, the indoor garden will therefore directly influence the eating practices of the elderly. However, in nursing homes for elderly people who do not suffer from dementia, residents choose whether or not they eat a certain dish (e.g., the fresh vegetables and herbs). Preferences then have a stronger effect on whether indoor gardens influence the eating practices of residents.

\subsection{The Cases, Their Gardens and Their Initial Cooking Routines}

The empirical material on which this paper is based was collected in four different nursing homes of healthcare organization Innoforte. In all four homes, a high-tech indoor garden was placed in March 2019, six months prior to this study. These high-tech indoor gardens were developed in collaboration with Vegger, a Dutch start-up. While Vegger is responsible for the maintenance of the gardens, the selection of crops was based on discussions with the management of Innoforte, and the employees and inhabitants of the nursing homes.

Innoforte, a foundation, offers housing, care and services to elderly people with different needs. The organization and its four nursing homes are all located in Velp, a small town located in the center of the Netherlands. Depending on the client's needs, Innoforte offers nursing home care, care with accommodation, temporary care, home care and day care. The four nursing homes differ in the type of residents (and therefore the type of required care), the way in which food is supplied and whether or not staff is hired specifically for cooking (Table 1). All of these differences potentially influence the effect of the high-tech indoor garden on cooking and eating practices. We now introduce the four nursing homes in more detail.

Table 1. Characteristics of Innoforte's nursing homes.

\begin{tabular}{ccccc}
\hline Nursing Home & Biesdel & Oosterwolde & 't Jagthuis & Lorentzhuis \\
\hline Type of residents & Without dementia & $\begin{array}{c}\text { With and without } \\
\text { dementia }\end{array}$ & With dementia & $\begin{array}{c}\text { With and without } \\
\text { dementia }\end{array}$ \\
\hline Food supply & Frozen meals & $\begin{array}{c}\text { Fresh and } \\
\text { non-fresh }\end{array}$ & Fresh ingredients & $\begin{array}{c}\text { Mainly fresh } \\
\text { ingredients }\end{array}$ \\
\hline Cooking staff & No chef & Chef & No chef & Chef \\
\hline
\end{tabular}

\subsubsection{Biesdel}

Biesdel offers care with permanent accommodation for 37 clients and temporary accommodation for seven clients. It also offers day care and meals for fifteen to twenty local elderly residents. In Biesdel, ready-to-eat-meals are served. The kitchen is designed to prepare frozen food efficiently. It has large multi-layered ovens in which large numbers of frozen meals can easily be prepared at once. The heated meals are brought to the restaurant in large bowls that are placed on rolling tables. Different employees, often working in pairs, take care of the meals: this is not a task appointed to a specific staff member. In Biesdel, the high-tech indoor garden was placed between the kitchen entrance and the restaurant, in the hallway that connects the restaurant to the apartments (Figure 1). The kitchen is located in the basement of the building, underneath the residences. 


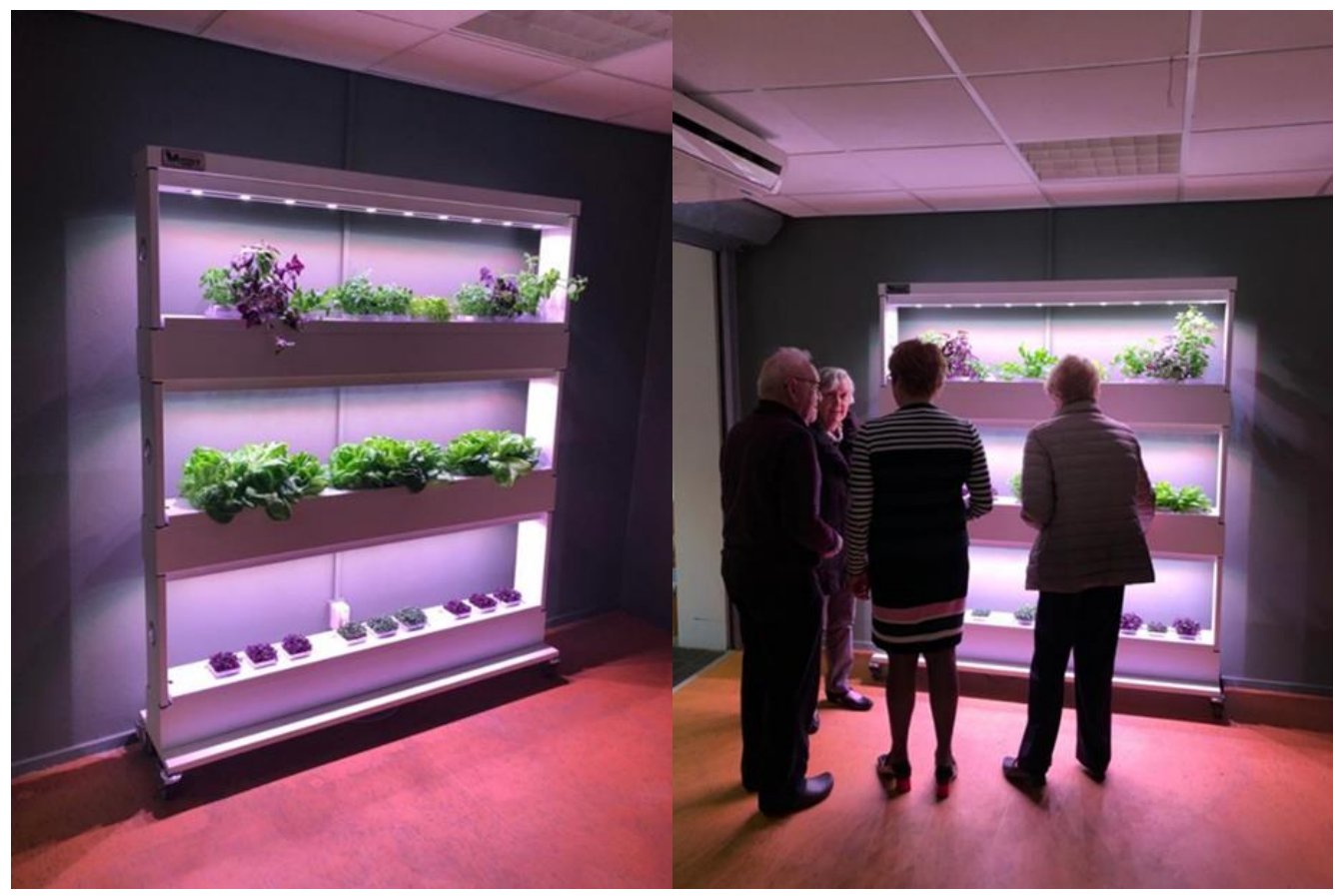

Figure 1. High-tech indoor garden in Biesdel (photos: first author).

\subsection{2. 't Jagthuis}

This nursing home offers small-scale psychogeriatric nursing home care for 67 clients suffering from dementia. Clients need intensive daily care and spend their day mostly in their living rooms. Cooking is done in various small kitchens, as part of the concept of 'small-scale living': people live in small groups of up to eight people, in housing units consisting of several bedrooms and a living room containing a kitchen. Each kitchen is equipped with a tablet that has an app for cooking. Employees use this app to order food and read the corresponding recipes that come with the ordered food, which mainly consists of fresh ingredients. The employees who take care of the elderly cook from time to time, but this is not their main task. The cooking is done individually (rather than in pairs). In't Jagthuis the garden was placed between a cosy corner with an imitation kitchen from the 1930s and the door to the backyard. The imitation kitchen is equipped with a table and some chairs where residents can sit (Figure 2).

\subsubsection{Lorentzhuis}

Lorentzhuis offers small-scale psychogeriatric nursing home care for 86 clients, living together in groups of up to eight people. It also offers care with accommodation for 26 clients who do not suffer from dementia. These people live in another part of the building, which also offers temporary accommodation for seven clients and day care and meals for fifteen to twenty older local elderly residents. A fixed, small group of employees cooks for this whole group at once, under the supervision of a professional cook. The open kitchen is adjacent to the restaurant/living room for day care. Elderly people with dementia only have access to this restaurant under the supervision of employees or family. Meal preparation for the 86 residents with dementia is similar to that in 't Jagthuis: cooking is done for each living group separately. The high-tech indoor garden was placed between the seating area of the restaurant and the hallway which connects the residences to the restaurant. Initially, the garden was placed elsewhere, but the location was changed in order to give the cooks easier access and to make the garden more visible to the elderly in the restaurant (Figure 3). 


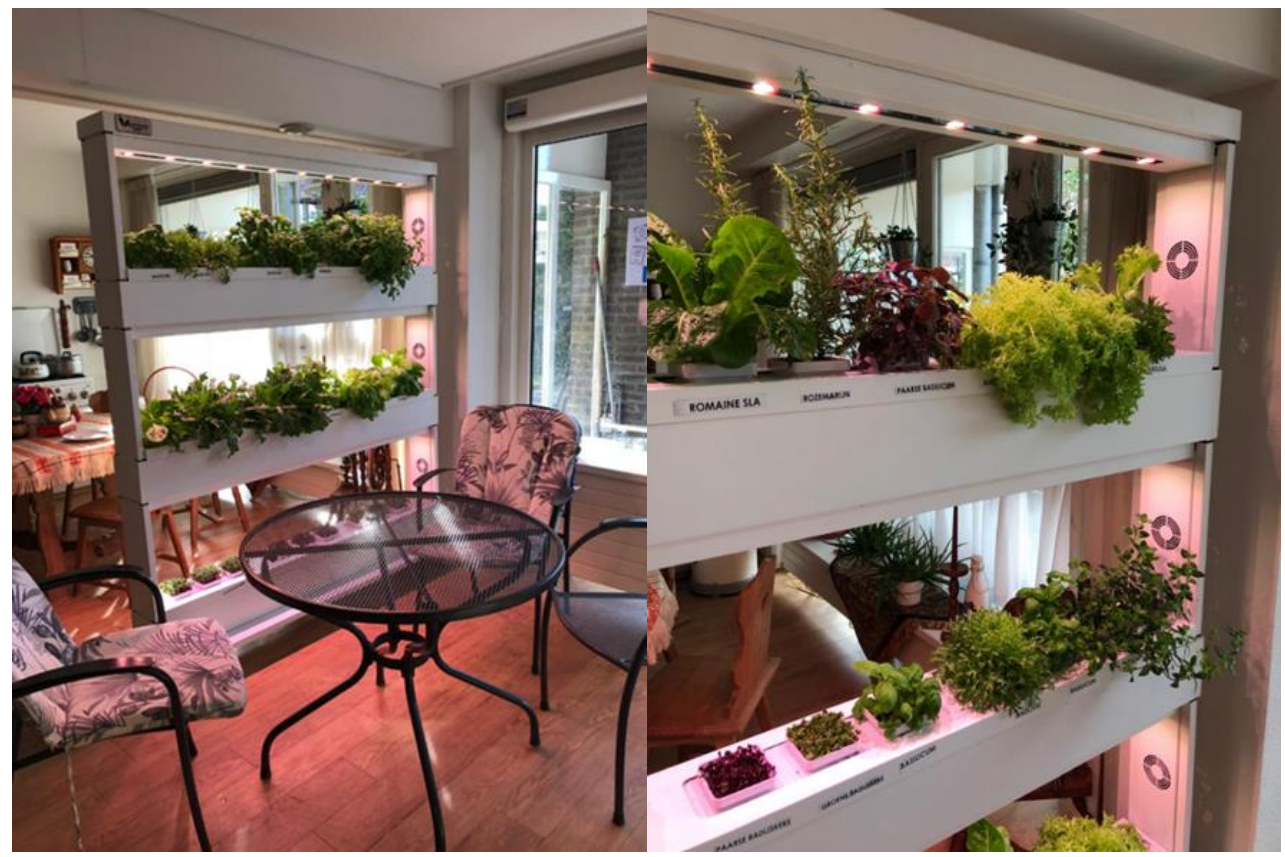

Figure 2. High-tech indoor garden in 't Jagthuis (photos: first author).

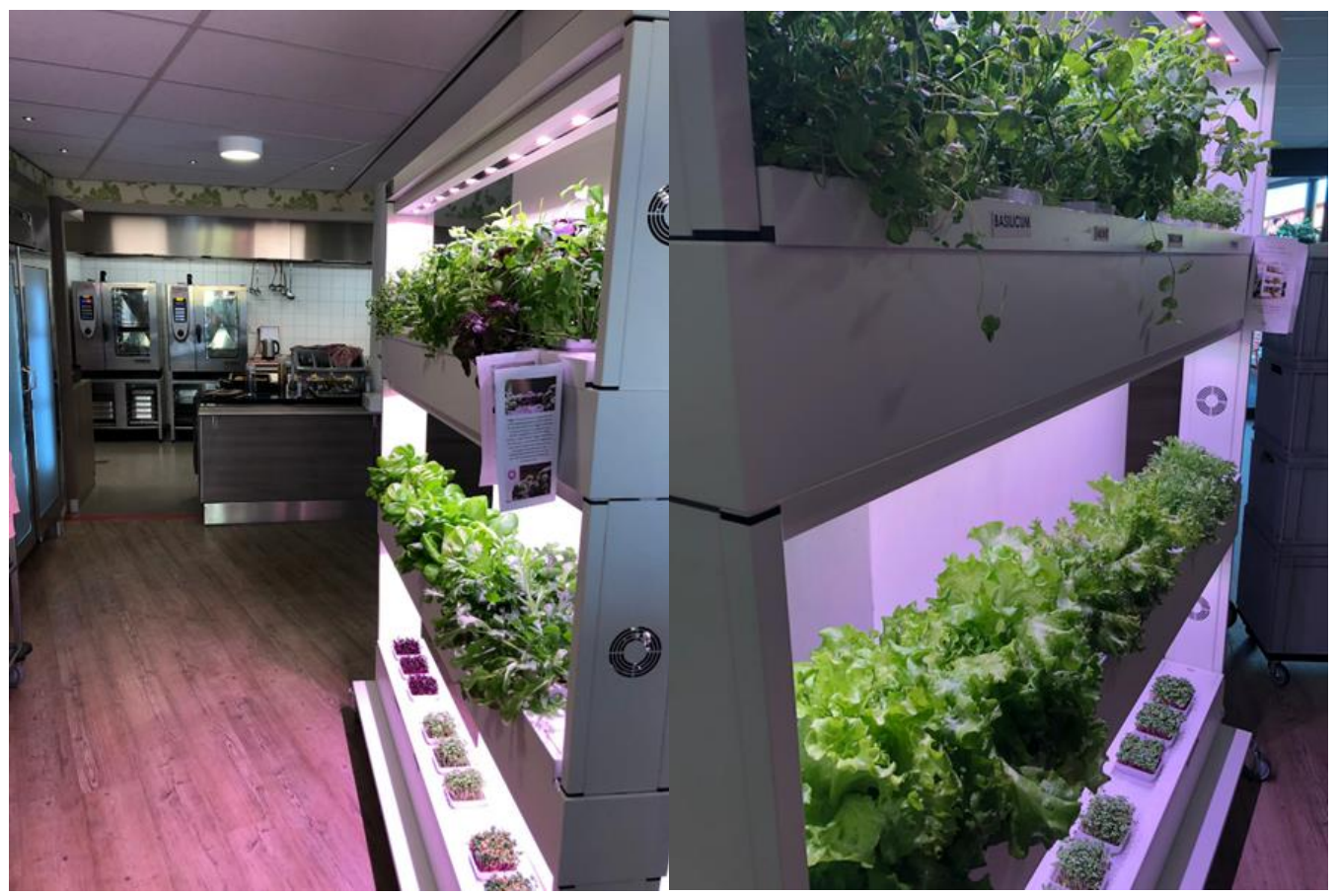

Figure 3. High-tech indoor garden in Lorentzhuis (photos: first author).

\subsubsection{Oosterwolde}

Oosterwolde offers somatic nursing home care for 36 clients and care with accommodation for thirty clients. In addition, it offers day care and meals for fifteen to twenty local elderly residents. The meal preparation in Oosterwolde is similar to that in Biesdel. Frozen food is delivered and heated in large ovens. Sauces and soups are made separately. As in Biesdel, cooking is done by a small group of employees, but there is often a chef present to guide the cooking process. Oosterwolde has a large open space close to its entrance where people receive visitors during the day, drink coffee and tea and 
consume their hot meals. The space has an open door to the kitchen, where only employees can enter. The high-tech indoor garden is placed near the open door to the kitchen (Figure 4).

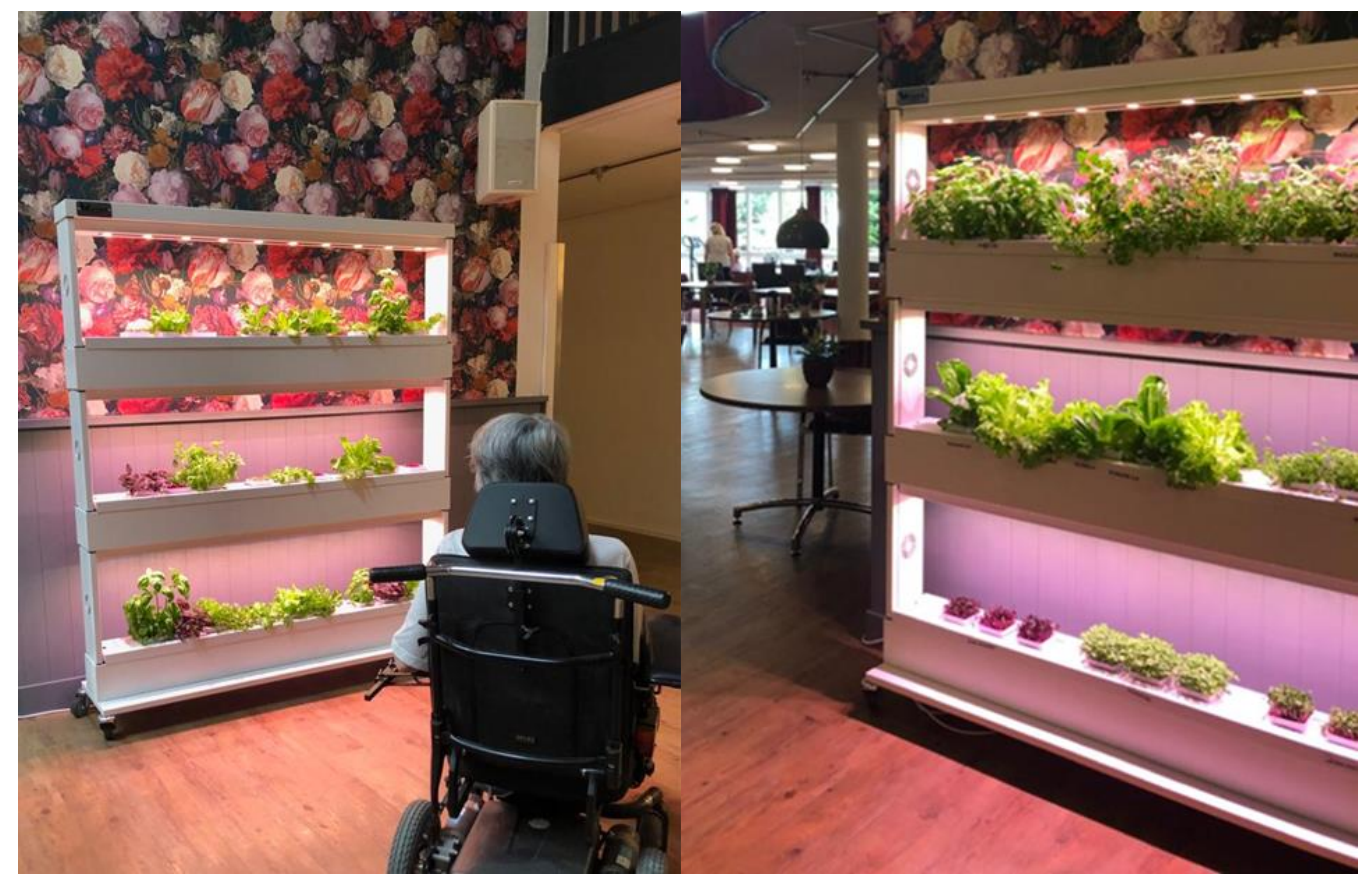

Figure 4. High-tech indoor garden in Oosterwolde (photos: first author).

\subsection{Data Collection}

We used both qualitative and quantitative methods to study cooking and eating practices in the four nursing homes, applying these to different populations in order to simultaneously broaden and strengthen the study. The mixed methods approach is used to ensure that the perceptions of decision makers, residents and employees are included in the findings of the study.

\subsubsection{Site Visits}

The first author regularly visited the different nursing homes. Between September and December 2019, she spent around three hours a week per location, divided between one or two visiting moments at various times of the day and week. Each location was visited approximately twenty times. During the visits, the first author observed the gardens, the restaurants and the kitchens, and interacted with the employees and inhabitants of the different locations informally. She kept notes of what she saw and heard. These notes serve as a contextualization of the answers of the executed survey. During the visits, photos were also taken of the high-tech indoor gardens and processes around them (e.g., harvesting) as a way to express and illustrate the findings of this research. Permission to take photos was asked in advance.

\subsubsection{Semi-Structured Interviews}

We conducted semi-structured interviews with (1) residents and (2) decision makers. Ten elderly people without dementia were interviewed, all living in Biesdel. We acknowledge that these residents only partially represent the group that is the subject of this research. However, it was not possible to interview the residents of the other locations because they suffer from dementia or other mental disabilities. The interviews with the 'healthy' elderly can give an indication of how others perceive the high-tech indoor gardens. The semi-structured interviews included several open-ended questions (see Appendix A), related to people's living environment, meals, plants, and leisure activities. The interviews took thirty minutes on average. The elderly people were reluctant to sign informed consent forms, as 
they often receive warnings not to sign anything. Moreover, they were not always able to read the forms. However, they all gave verbal consent, and we made sure to explain the purpose of the study in detail, emphasizing that participation was voluntary and could be stopped at any moment.

The elderly people were found through opportunity sampling, as contact persons from the nursing homes indicated that this would be the best way to approach them. Hence, the first author sat down at residents' tables during coffee time. As a result of this strategy she sometimes spoke to several elderly residents simultaneously, resulting in lively conversations. The elderly people whom she spoke to individually were less motivated to talk than the elderly people with whom she spoke in pairs.

We also interviewed two decision makers: Innoforte's facility manager and a food expert, both responsible for all four nursing homes. Interviewing the facility manager gave a better understanding of how high-tech indoor gardens are included in the facility management of the location. The food expert is responsible for guiding and motivating the employees to use the vegetables and herbs from the high-tech indoor gardens in the meals. He transfers the practices of high-tech indoor gardening to the employees and volunteers of the nursing homes. The interview with the food expert gave more insights about how this is done. All interviews, both with residents and with decision makers, were recorded and transcribed.

\subsubsection{Surveys}

We used surveys to examine the perspectives of employees and volunteers in all four nursing homes, targeting those involved in cooking practices. These include chefs, service employees, food assistants, care givers and hostesses. Employees active in, for instance, management, cleaning and technical service were not considered as part of the target group. The total population of the target group was 25 people (based on an estimation of the food expert). As employees in nursing homes are busy with their daily tasks, it was considered more effective to use a survey rather than interviews. The survey provided information on employees' competences and experiences related to gardening and cooking and gave insights into their motivation to use (or not) the indoor gardens. It contained 25 questions, both multiple choice and open questions (see Appendix B). Surveys were handed directly to the employees and left at the front desks of all locations. Secretaries at front desks assisted by handing over the surveys to their colleagues and motivating them to fill them out, leading to a total of 22 completed surveys. Table A1 shows the demographic characteristics and job titles of the survey respondents (see Appendix C). As analysis software we used SPSS (IBM Corp. Released 2016. IBM SPSS Statistics for Windows, Version 24.0. Armonk, NY: IBM Corp.). We conducted Fisher's Exact Tests because of its accuracy in analysing data in studies with small sample sizes [37].

\section{Results}

In this section, we explain how the indoor gardens influence cooking and eating practices. We first focus on the cooking practices of employees, after which we describe the effects on the eating practices of residents.

\subsection{Cooking Practices}

Rather than studying the entire cooking process, the focus of our research is on how employees engage the indoor gardens in their cooking practices. As argued in Section 2.1 we consider cooking as a variety of tasks related to the preparation of the meal: harvesting is one of those tasks. Nursing home employees are responsible for harvesting the vegetables and herbs from the indoor gardens, and for incorporating these fresh ingredients into the meals for the residents. At all four locations, employees harvest fresh vegetables and herbs from the indoor gardens. However, there are differences in the amount of produce they harvest. Per month, 108 plantation pots are available for harvest: 27 plants per week. In Lorentzhuis, these were all harvested consistently. In Biesdel, employees harvested on average 92 plants per month. In Oosterwolde, around 88 plants per month were harvested. In 't Jagthuis, the number of harvested plants was significantly lower, with an average of 41 harvested 
plants per month. At each location, the garden contained a mix of different crops, with different lettuce plants, basil, mint, thyme, rosemary, endive, chives, parsley and sprouting vegetables. In 't Jagthuis, the thyme, rosemary, basil and mint were harvested less frequently than the other plants.

Both the survey and the site visits indicate that gardening experience influences whether staff harvest vegetables and herbs and whether they incorporate them into their cooking practices. The survey shows that employees with gardening experience are more likely to harvest vegetables and herbs from the garden than employees without gardening experience (Figure 5). A Fisher's Exact test shows that this relationship between gardening experience and harvesting is significant: if employees have gardening experience, they are more likely to harvest from the indoor garden, $p=0.042$.

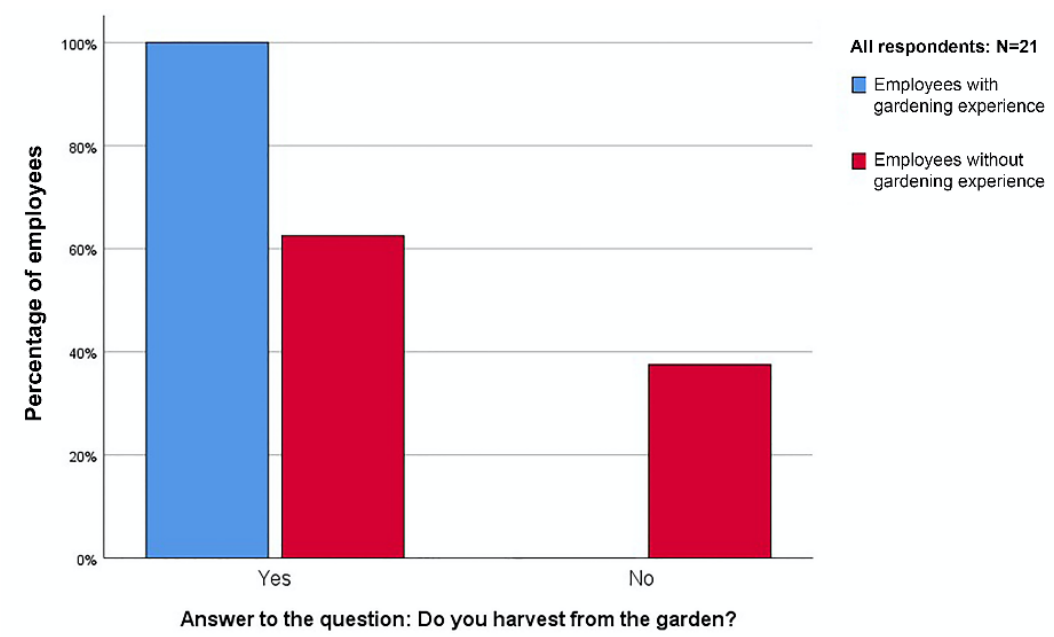

Figure 5. Distribution of relationship between gardening experience and interest in harvesting from the gardens. The vegetables and herbs are processed in the kitchen or served with the meal immediately after harvesting. Crops such as lettuce are mainly used to make a side dish such as a salad and the sprouting vegetables are usually served raw with the meal (Figure 6). Herbs are served mainly as a flavour enhancer in the soup. We found that the extent to which employees use the garden produce in the cooking practices not only depends on their gardening experience, but also on their cooking competences. These competences are different in the four nursing homes. In Oosterwolde and Lorentzhuis, a professional chef is present. These chefs are trained to prepare meals in nursing homes, and they are in charge of the kitchens: they have ample knowledge and experience in cooking. Chefs in Oosterwolde and Lorentzhuis do not need much advice or motivation from the food expert to use fresh vegetables and herbs from the gardens in the meals. They harvest the crops and know how to use them. Biesdel and ' $t$ Jagthuis do not employ professional chefs, but the food expert explained that the employees at Biesdel are more experienced in cooking (and therefore harvest more often) than those in ' $t$ Jagthuis. Some employees have been working at Biesdel for more than thirty years, and have experienced many changes in care, including food preparation. As a result, Biesdel employees have a lot of cooking experience. When younger employees have to prepare the food, they are almost always accompanied by an older employee, resulting in an exchange of knowledge regarding cooking. Working together can encourage better integration of the vegetables and herbs in the meals, because employees can share ideas and experiences. Moreover, in Biesdel, the same employees are often in charge of cooking. These employees, therefore, gain cooking experience and competences. 


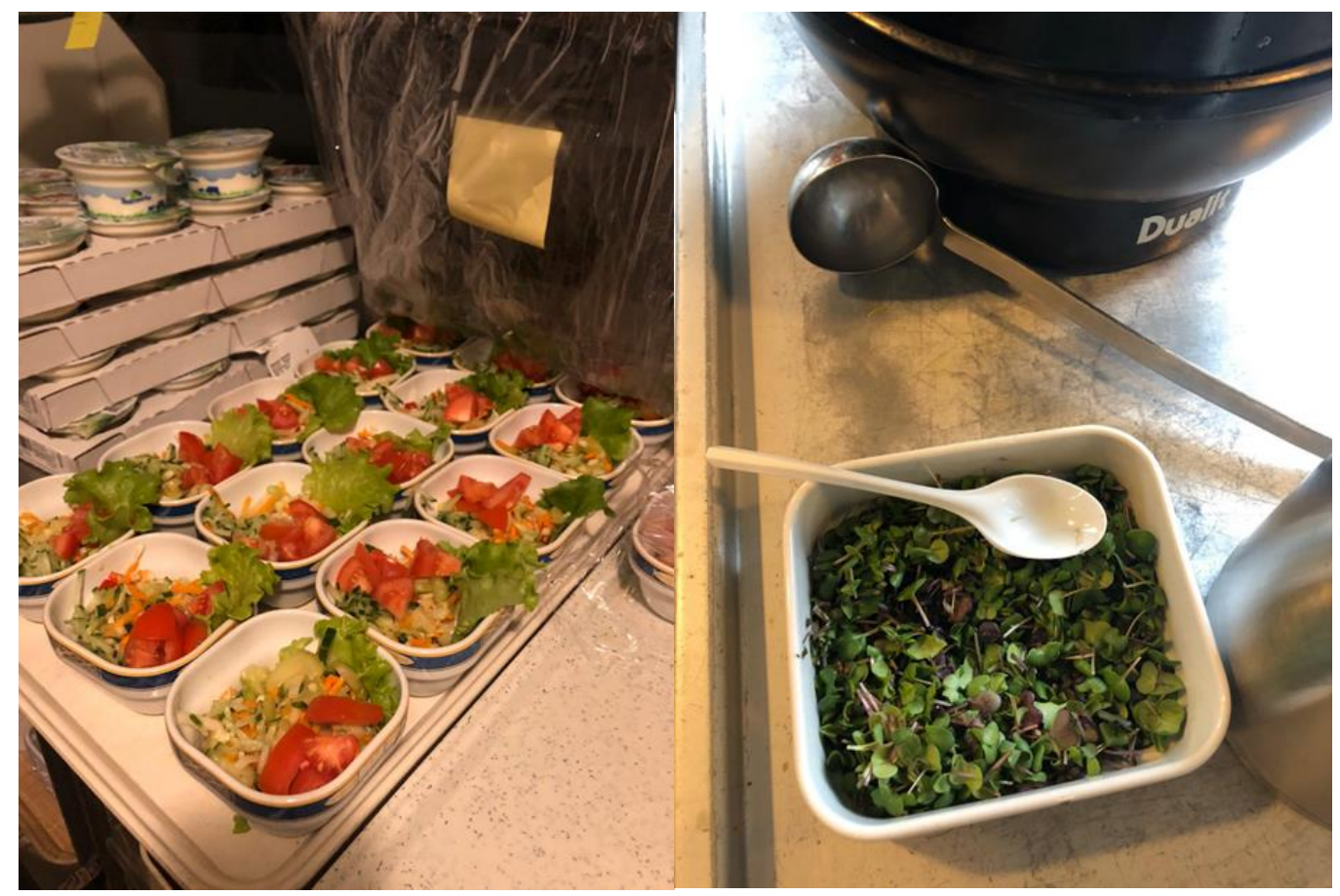

Figure 6. Servings made with products from the garden (photos: first author).

Observations revealed that employees communicate with their colleagues about the type of plants grown in the indoor gardens and what experience they have with them. During site visits, some cooks expressed that they have their own vegetable garden at home. One of the chefs in Lorentzhuis explained that she sometimes brings home-grown products from her garden to the nursing home, so that these would not go to waste. During the interview, the food expert also observed that some employees have more affinity with fresh, local vegetables, which leads to increased use of the fresh vegetables and herbs during cooking.

In contrast to the employees of Biesdel, the employees of ' $t$ Jagthuis have several different tasks. They cook only occasionally. This results in less cooking experience and fewer cooking skills. As explained by the facility manager: "The people who are responsible for cooking [in't Jagthuis], are people with a background in care and they often have no experience as a cook. (...) They just see it [cooking] as a side task." For employees working in 't Jagthuis, cooking is thus only one of their responsibilities, and the practice is not always performed by the same people. As a result, employees lack the knowledge and competences required for cooking with the harvest, which means that they harvest less frequently. Moreover, employees in 't Jagthuis both cook and harvest individually. In the other three homes, employees work collectively in one large kitchen: they can therefore exchange experience in cooking and harvesting. Observations showed that employees in these three homes almost always harvest in pairs, and that they harvest more often than in ' $t$ Jagthuis. This suggests that colleagues can encourage each other to harvest and that employees may enjoy harvesting together rather than on their own.

Besides the availability of harvesting and cooking competences, whether or not employees enjoy cooking also matters for whether they use the indoor garden in their cooking practices. Fifteen out of the 22 employees consider cooking a fun activity. When employees enjoy cooking, they show more interest in harvesting from indoor gardens and subsequently changing their cooking practice. A Fisher's Exact Test confirms that there is a significant relationship between enjoying cooking and harvesting, $p=0.023$. In other words, employees who see cooking as a fun activity are more likely to harvest from the garden (Figure 7). 


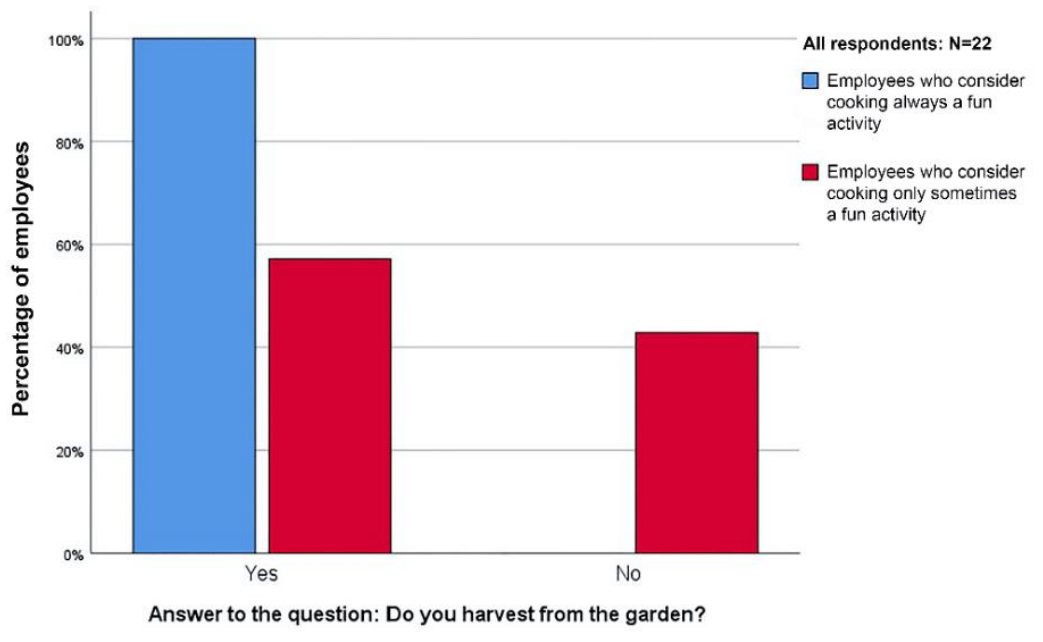

Figure 7. Distribution of relationship between considering cooking a fun activity and integration of vegetables from indoor garden in cooking practices.

Our research also shows that indoor gardens do not require much extra equipment in the kitchen in order to serve the produce. While the kitchen in Lorentzhuis was recently renovated to facilitate serving fresh meals to the residents (with, among other things, multiple refrigerators and stoves), Biesdel has an older kitchen, with large ovens to warm up frozen meals. Earlier attempts to integrate fresh vegetables in meal preparation of Biesdel failed, because the kitchen did not have the right equipment to process fresh vegetables. The food expert explained: "When I order twenty endives from a local farmer, I have to cut them, I have to wash them. I have small sinks here. I don't have material to put it in [ ... ] I can only make soup and sauce here". Despite this lack of proper equipment to process fresh ingredients, using the indoor garden is a practice that fits well within the limits of Biesdel for different reasons. First of all, the vegetables and herbs function as a (raw) additive to the food: they do not need to be cooked. Secondly, the plants stay fresh as long as they stay in the garden, and they are harvested right before they are consumed. Fridges to keep the ingredients fresh are thus not needed. The difference between Lorentzhuis and Biesdel shows that the presence of kitchen equipment for storing and cooking fresh ingredients is needed to transform the cooking practices in a broader sense (i.e., to replace heating ready-made meals with cooking from scratch), but that the characteristics of the indoor garden enable it to be used in kitchens lacking such equipment.

Finally, whether employees already used fresh produce before the introduction of the gardens influences the extent to which they integrate the gardens' harvests in their cooking practices. Some of the nursing homes use frozen meals, while other nursing homes mainly prepare meals with fresh ingredients. At the locations where non fresh ingredients (including frozen meals) are used, employees harvest from the garden on a weekly basis (Figure 8). A Fisher's Exact Test confirms that in nursing homes in which employees use non fresh ingredients, vegetables and herbs from the garden are more often harvested than in nursing homes where employees already cook with fresh ingredients, $p=0.042$.

Indeed, Biesdel employees, who are accustomed to heating frozen meals, mentioned in the survey that the fresh vegetables and herbs from the garden contribute to the meal because of their colour and taste. In 't Jagthuis, however, where cooking from scratch is the norm, survey respondents do not necessarily expect products from the garden to contribute to residents' meals. These results suggest that the use of fresh produce in existing cooking practices might result in a more limited motivation to harvest from the garden. 


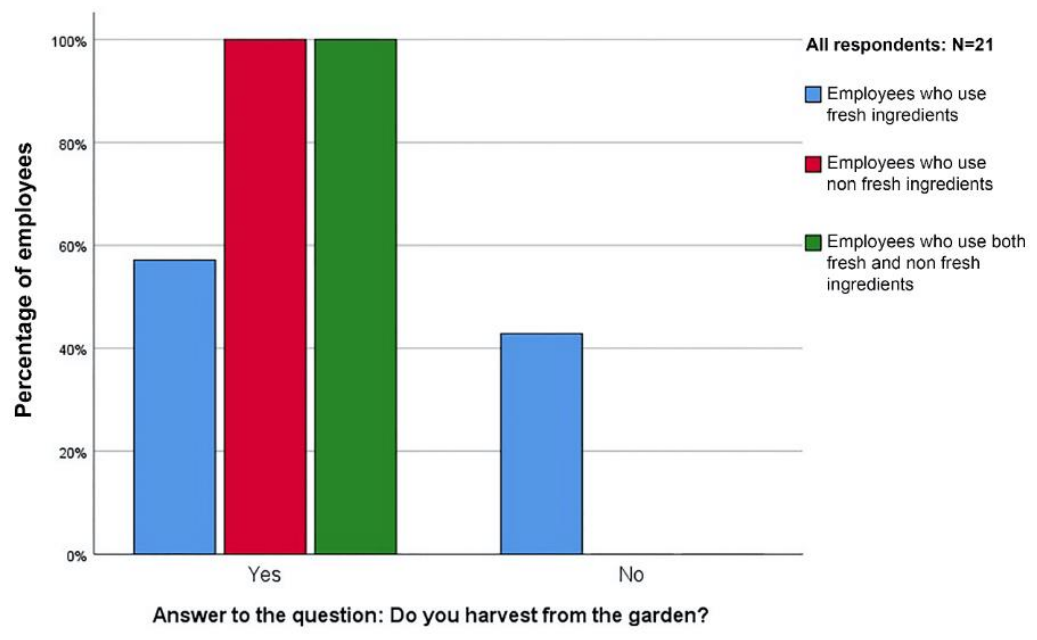

Figure 8. Distribution of relationship between ingredients used in current cooking practices (fresh versus non fresh) and integration of indoor gardens in cooking.

\subsection{Eating Practices}

The facility manager aims to offer residents food that is healthy and that encourages them to eat more, so as to prevent malnutrition and to contribute to residents' well-being. She supports the indoor gardens because she believes that they contribute to health in two ways: the produce is not treated with pesticides that can harm the health of the elderly residents, and the harvest can stimulate food intake because it is used to create side dishes (residents eat more when they are presented with multiple dishes rather than one big plate). Moreover, the facility manager stated that the indoor gardens changed the experience of the meal for residents in positive ways.

All ten residents interviewed expressed that they enjoy consuming the fresh vegetables and herbs from the indoor gardens: "I like it with the soup", and "I like it in in the salad, too". They described the vegetables and herbs as 'tasty', 'fresh' and 'delicious'. Especially the freshness of the vegetables and herbs was often mentioned as enjoyable. Most of the residents we spoke to in interviews and when visiting the nursing homes argued that they can taste the freshness of the vegetables and herbs. They explained that they could clearly distinguish the difference between a meal prepared with the vegetables from the indoor gardens and a dish without fresh vegetables. They find it important to eat fresh food, and they appreciate the fresh taste of the vegetables and herbs: "It has a lot of flavour", and "especially the ones, what do you call them, the bowl with lettuce [referring to side dishes]. That's very fresh".

During the consumption of the meal, residents can see the indoor gardens and the plants that grow there, and when they are waiting for their meals, they can see employees harvest the vegetables and herbs and use them in the dishes. Various interviewees from all four nursing homes expressed that they appreciate the fact that the vegetables and herbs are grown locally. Several residents also argued that it has added value when vegetables are grown in a responsible manner. One of the residents said: "Often when you buy vegetables, it's been treated and sprayed [with pesticides]." Interviewees appreciate the way the vegetables and herbs from the garden are produced, which contributes to the motivation to eat them. This is also due to the fact that several of the residents interviewed have experience with gardening and are familiar with growing local food: "I enjoyed my vegetable garden a lot. Healthy and fresh. I think that's important." When one of the residents said "I've always had a vegetable garden. We always ate everything from our own garden", his neighbour replied, "That's why you're in such good condition. That's very healthy." Indeed, residents see the meals as 'healthier', and 'more fun' when vegetables and herbs from the indoor gardens are used.

Finally, the smell of the fresh vegetables and herbs plays a role in the experience of the meal. During observations we heard several residents say, "It smells good", and one interviewee stated: "I hear that also others like the smell", indicating that residents even communicate about the smell of the plants. 


\section{Discussion}

High-tech indoor gardening may be considered as a new or emerging practice. While it can be argued that growing food inside a building by using a high-tech system is an alteration of the yet-existing gardening practice, for those living and working in nursing homes it is a new practice within that specific environment. Moreover, the indoor gardening practice results in a transformation of some of the existing practices in nursing homes: high-tech indoor gardens allow the local production of vegetables and herbs, which changes the way food is prepared and, in turn, eaten. Employees have (more) access to fresh vegetables and herbs, which they acquire through harvesting. This changes the processes around food preparation in which they engage. Residents encounter a more transparent process of growing and preparing food, and they appreciate the fresher taste of the meals they consume. Other studies confirm that vegetable gardens can help in improving the diets of people surrounded by them: Graham and Cher [38] found that gardens can promote healthy eating behaviours among students, whereas Spees et al. [39] showed that urban gardens can lead to greater dietary intake among cancer survivors.

In order to better understand the impact of indoor gardens on the transformation of cooking and eating practices within nursing homes, we now discuss these two practices in terms of the three constitutive elements of practices as defined by Shove et al. [33]: meaning, competence and material. In this paper, we discussed the practice of cooking in relation to employees and the practice of eating in relation to residents. Nevertheless, while residents and employees are connected to the gardens in different ways, the meaning the gardens have for them is fairly similar. In general, the garden is associated with freshness, which translates to good flavour for the residents and to health for employees. Ideas of freshness, flavour and health are boosted by the transparency of and therefore trust in the production process. Hence, both the characteristics of the food itself and the fact that it is being grown and prepared close to the consumer (which, for some residents and employees, relates to their own gardening experience) increases the appreciation of the meal.

Zooming in on competences, the comparison between Biesdel and 't Jagthuis shows that the different ways in which the cooking practice is organised in the nursing homes influences the ease with which the gardening practice is integrated into the cooking practice. Unlike in ' $t$ Jagthuis, where cooking practices are decentralised and performed by almost all employees, cooking in Biesdel is performed by specific people. They can more easily adopt new practices and change food preparation processes. The centrality of the practice eases the integration of novelties and the acquisition of new competences. Another strategy to integrate the garden in the cooking practice is the use of a professional chef, as in Lorentzhuis and Oosterwolde. These chefs have ample experience in cooking and are creative in using the vegetables and herbs from the indoor garden. They have the competences required for adjusting the cooking practice to the reality of the indoor garden, enabling the integration of gardening and cooking. Finally, we also found a relationship between gardening experience and harvesting. Employees with experience in gardening show more affinity with the use of the indoor gardens, which facilitates harvesting and the subsequent integration of vegetables and herbs into cooking practices.

It is important to mention that a possible correlation between the various factors that limit the integration of fresh vegetables and herbs from the garden in the cooking practices cannot be ruled out. We found that employees who already cook with fresh vegetables seem less motivated to use the garden produce in residents' meals, and that employees with limited gardening experience are less likely to harvest from the gardens: in some cases, however, these are the same people. In 't Jagthuis, where the indoor garden is used less frequently than in the other nursing homes, all employees already use fresh ingredients for cooking, while most of them have no gardening experience. Moreover, all residents living in 't Jagthuis suffer from dementia. It is possible that this contributes to a limited motivation to harvest among employees, as these residents may be less aware of the food they consume. This hypothesis, as well as the potential correlation between factors that limit or stimulate harvesting, warrants further research. 
Finally, the introduction of high-tech indoor gardens influences the material dimension of cooking practices in nursing homes in different ways. First, gardens introduce new materials-fresh vegetables and herbs-to be used in cooking, without requiring different or improved kitchen equipment. The materiality of the garden itself enables harvesting the crops right before consumption, keeping them fresh for as long as needed. This gives the garden an advantage over fresh vegetables from other places such as the wholesaler. Second, material also plays a role with respect to the location of the indoor garden. We illustrate this with an example from Lorentzhuis. Initially, the garden was placed in the communal living room for elderly suffering from dementia. Before entering this room, employees needed to pass a locked door. At that time only a few plants a week were harvested. Upon insistence of the chef, the garden was moved to the open kitchen and restaurant, after which all plants were harvested every week. This suggests that when the garden is located close to the kitchen, the integration of harvesting into cooking practices is facilitated. Engaging in harvesting does not require extra time and effort, which makes it easier for employees to transform their cooking practices.

Our work shows that this new type of food supply system can be valuable for residents in Dutch nursing homes. It suggests that gardens can influence the food intake of the residents by improving freshness, flavour and trust in the food. It is likely that this increased trust in the quality of the harvest and the way the elderly experience their meals contributes to a higher intake of vegetables and herbs. As argued, new practices have a higher chance of being adopted when they carry recognizable and familiar elements. Indeed, the new practice of indoor gardening is more easily performed by employees who are more confident with related practices, such as gardening/harvesting and cooking. The gardens do not require specific material arrangements to be made, easing their integration in cooking, but our work also shows that employees are less ready to harvest when the added value of the gardens is limited (i.e., when employees already cook with fresh ingredients). Finally, the meaning of indoor gardening fits ideas about what a good meal is. Hence, our work suggests that this new practice is relatively easily 'embedded in the details of daily life' [36] because of its links to existing materials, competences and meanings.

An important limitation of our work is that we did not specifically collect data on the quantity of consumed food. In order to get a better understanding of the contribution of indoor gardens to the actual food intake of elderly residents, future research should apply quantitative research methods to measure food intake before and after the introduction of an indoor garden. Moreover, the number of interviewees in our study was limited and the sample size for the survey was rather small. Future research should therefore include more nursing homes to get higher sample sizes for more dependable data.

\section{Conclusions}

The aim of this explorative study was to understand to what extent high-tech indoor gardens influence the cooking and eating practices in nursing homes, and what is needed to enable such changes. In the four nursing homes studied for this paper, the installation of indoor gardens resulted in an integration of harvesting (and the harvest) into cooking practices, which in turn transformed residents' eating practices. Appreciation of the taste of fresh vegetables and appearance of the meal decorated by fresh herbs holds value for the elderly residents, and employees appreciate the possibility to serve healthier meals. We found that the integration of indoor gardens in existing cooking practices is more successful when employees have gardening and/or cooking competences, when they enjoy cooking and when they do not already cook with fresh ingredients. The indoor gardens are also more easily integrated when they are easily accessible. The materiality of the garden enables using the produce even in not fully equipped kitchens.

High-tech indoor gardens are a relatively recent phenomenon within the field of urban agriculture. Urban agriculture is associated with various benefits, both social (such as better access to fresh food, improved social cohesion, and more green and liveable cities) and environmental (like cleaner production methods, fewer food miles, and a reduction of the heat island effect). Unlike urban 
agriculture more broadly, high-tech indoor gardens do not green the city as such. However, as stated in the beginning of this paper, the production methods used in high-tech indoor gardens are relatively clean and highly efficient. Moreover, by bringing vegetables and herbs into the living space, indoor gardens influence the lives of nursing home residents. They create more pleasant indoor environments, which is specifically important to people who spend limited time outdoors. They offer something to see, touch and smell, which may trigger memories and serve as a topic for discussion, potentially strengthening social cohesion (as is suggested by research on community gardens, see, for instance, [40,41]). Therefore, despite the fact that the harvest from the gardens studied in this paper is relatively small, so that the direct influence on vegetable intake is limited, it seems that Farhangi et al. [42] may be right when they state that a transition towards high-tech urban agriculture as an alternative food production method can help to deal with the social and environmental issues caused by the industrial food system in the Netherlands.

Author Contributions: Conceptualization, P.C.H.v.d.V. and E.J.V.; Methodology, P.C.H.v.d.V. and E.J.V.; Software, P.C.H.v.d.V.; Validation, P.C.H.v.d.V. and E.J.V.; Formal analysis, P.C.H.v.d.V.; Investigation, P.C.H.v.d.V.; Resources, P.C.H.v.d.V.; Data curation, P.C.H.v.d.V.; Writing—original draft preparation, P.C.H.v.d.V. and E.J.V.; Writing-review and editing, P.C.H.v.d.V. and E.J.V.; Visualization, P.C.H.v.d.V.; Supervision, E.J.V.; Project administration, P.C.H.v.d.V.; All authors have read and agreed to the published version of the manuscript.

Funding: This research received no external funding.

Acknowledgments: This research would not have been possible without the support and collaboration of the employees and residents of Innoforte Foundation and in particular the facility manager of Innoforte, Marie-Jose de Dreu.

Conflicts of Interest: The authors declare no conflict of interest.

\section{Appendix A}

Interview guides (translated from Dutch)

Interview guide-residents

\section{BACKGROUND QUESTIONS}

1. How long have you been living here?

2. Which facilities within Innoforte do you find comfortable?

3. Which meals are provided for you? (Breakfast/lunch/dinner)

4. To what extent do you think the meals are tasty?

5. To what extent do you think the meals are healthy?

6. How important is fresh food to you?

\section{LIVING ENVIRONMENT}

7. What do you think of your living environment?

8. How often do you take a walk outside?

9. What do you think of the interior here?

10. To what extent does a 'green' interior contribute to a pleasant interior for you?

11. What do you think of the indoor vegetable garden?

12. To what extent does the indoor vegetable garden contribute to a nicer space?

13. To what extent does the indoor vegetable garden contribute to a pleasant space?

14. What do you think of the smell? What do you think of the colour? What do you think of the lighting? 


\section{MEALS}

15. To wat extent do you taste a difference between meals with and meals without vegetables and herbs from the indoor vegetable garden?

16. What do you think about the taste of the produce from the garden?

17. Do you like it when products from the garden are used in the meal? Why/why not?

Interview guide-facility manager/food expert

\section{BACKGROUND QUESTIONS}

1. How long have you been working in this sector (elderly care)?

2. How long have you been working at Innoforte?

3. What differences do you recognise between the four Innoforte locations in terms of...

... Residents?

... Food supply?

... Staff?

\section{HEALING ENVIRONMENT}

4. What does the term 'healing environment' mean to you?

5. Innoforte is working on the development of healing environments. Is applying/creating a healing environment important to you? Why?

6. How does the indoor vegetable garden fit into your vision of care and healing environments?

7. What is the importance of fresh food within the Innoforte organization?

8. How much has changed in food and nutrition since you started working here? (What kind of changes?)

9. In what other ways does Innoforte try to work on healing environments? Are there differences between the locations regarding the healing environment?

\section{STAFF}

10. Which people are responsible for meal preparation? How does this differ between the locations?

11. Do you try to facilitate the transfer of knowledge? How?

12. What is the importance of fresh food within the Innoforte organization?

13. What role do you play in the transfer of knowledge to Innoforte's staff regarding food preparation? How does this knowledge transfer work?

14. How do you think the staff deals with the indoor vegetable garden? Do you think they make enough use of it (harvesting)? Why/why not?

15. How is the knowledge transfer with regard to the use of the indoor vegetable garden?

16. Are there differences between the locations on how this knowledge is received/applied? What are these differences? Can you explain why they are there? Are there differences within the locations? Why?

\section{MEALS}

17. What is going well in terms of the use of the garden in meal preparation, and what could be better?

18. Are there differences per location?

19. How do you think the indoor vegetable garden influences meals within Innoforte?

20. Do you think it contributes to the experience of the meal?

21. How do you think the residents appreciate the indoor garden? (Do they talk about it? Do they like to sit close to the garden?) 


\section{Appendix B}

\section{Survey for employees (translated from Dutch)}

\begin{tabular}{|c|c|c|c|c|}
\hline BACKGROUND & & & & \\
\hline 1. Are you employed or & volunteer? & & & \\
\hline$\square$ Employed & & $\square$ Volunt & & \\
\hline 2. How old are you? & & & & \\
\hline$\square$ Younger than 20 years & $\square$ 20-34 years & $\square$ 35-44 years & $\square$ 45-59 years & $\square 60$ years or older \\
\hline 3. For how long have yo & been working $\mathrm{i}$ & Iderly care? & & \\
\hline$\square 5$ years or less & $\square$ 6-10 years & $\square$ 11-20 years & $\square$ 21-30 years & $\square$ More than 30 year \\
\hline
\end{tabular}

4. What is your role within Innoforte? (You can tick multiple boxes)

\begin{tabular}{lllll}
\hline$\square$ Food assistant & $\square$ Caregiver & $\begin{array}{l}\square \text { Nurse } \\
\text { (vocational } \\
\text { educated) }\end{array}$ & $\begin{array}{l}\square \text { Activity } \\
\text { Supervisor }\end{array}$ & $\square$ Service employee \\
\hline$\square$ Team leader & $\square$ Chef & $\begin{array}{l}\square \text { Nurse (BSc } \\
\text { educated) }\end{array}$ & $\square$ Nurse & $\square$ Hostess \\
\hline
\end{tabular}

$\square$ Receptionist $\quad \square$ Other:...

5. At which Innoforte location do you work?

\begin{tabular}{lcc}
\hline$\square$ 't Jachthuis $\quad \square$ Biesdel & $\square$ Lorentzhuis & \\
\hline 6. Do you work with elderly people suffering from dementia? & \\
\hline$\square$ Yes & $\square$ No & \\
\hline 7. How many days a week do you work? & $\square$ 2-3 days a week & $\square$ 4-5 days a week \\
\hline$\square$ 1 day a week or less & & \\
COOKING
\end{tabular}

8. How many times a week do you work in the kitchen/do you cook for the residents?
$\square$ Never $\rightarrow$ continue with question 14
$\square$ once a week or less
$\square$ 2-3 times a week
$\square$ More than 3 times a week

9. What kind of ingredients do you use for this?
$\square$ Fresh ingredients
$\square$ Fresh and non fresh ingredients
$\square$ Non fresh ingredients
$\square$ Other: ...

10. Do you like the task of cooking? Do you enjoy cooking?

\begin{tabular}{|c|c|c|c|}
\hline$\square$ Yes & $\square$ No & $\square$ Sometimes & $\square$ Other \\
\hline \multicolumn{4}{|c|}{ 11. How important is fresh food to yourself? } \\
\hline $\begin{array}{l}\square \text { Very important, I } \\
\text { (almost) always } \\
\text { cook/eat fresh }\end{array}$ & $\begin{array}{l}\square \text { Important, I often } \\
\text { cook/eat fresh food }\end{array}$ & $\begin{array}{l}\square \text { Not that important, I } \\
\text { cook/eat fresh sometimes }\end{array}$ & $\begin{array}{l}\square \text { Not important, I (almost) } \\
\text { never cook/eat fresh }\end{array}$ \\
\hline
\end{tabular}

12. Do you ever harvest from the indoor vegetable garden? Why or not?

$\square$ Yes, because ...

$\square$ No, because ...

13. When you use vegetables from the indoor vegetable garden, do you tell the residents?
$\square$ Yes, always
$\square$ Yes, usually
$\square$ No, usually not
$\square$ No, never 


\begin{tabular}{lll}
\hline 14. Do you think the meals for the residents are healthy? & \\
\begin{tabular}{llll}
\hline They are very & $\square$ They are quite & $\square$ They are not that \\
healthy & healthy & $\begin{array}{l}\square \text { They are not } \\
\text { healthy at all }\end{array}$ & $\square$ Idon't know \\
\hline
\end{tabular}
\end{tabular}

15. Do you think the indoor vegetable garden contributes to a healthier meal?

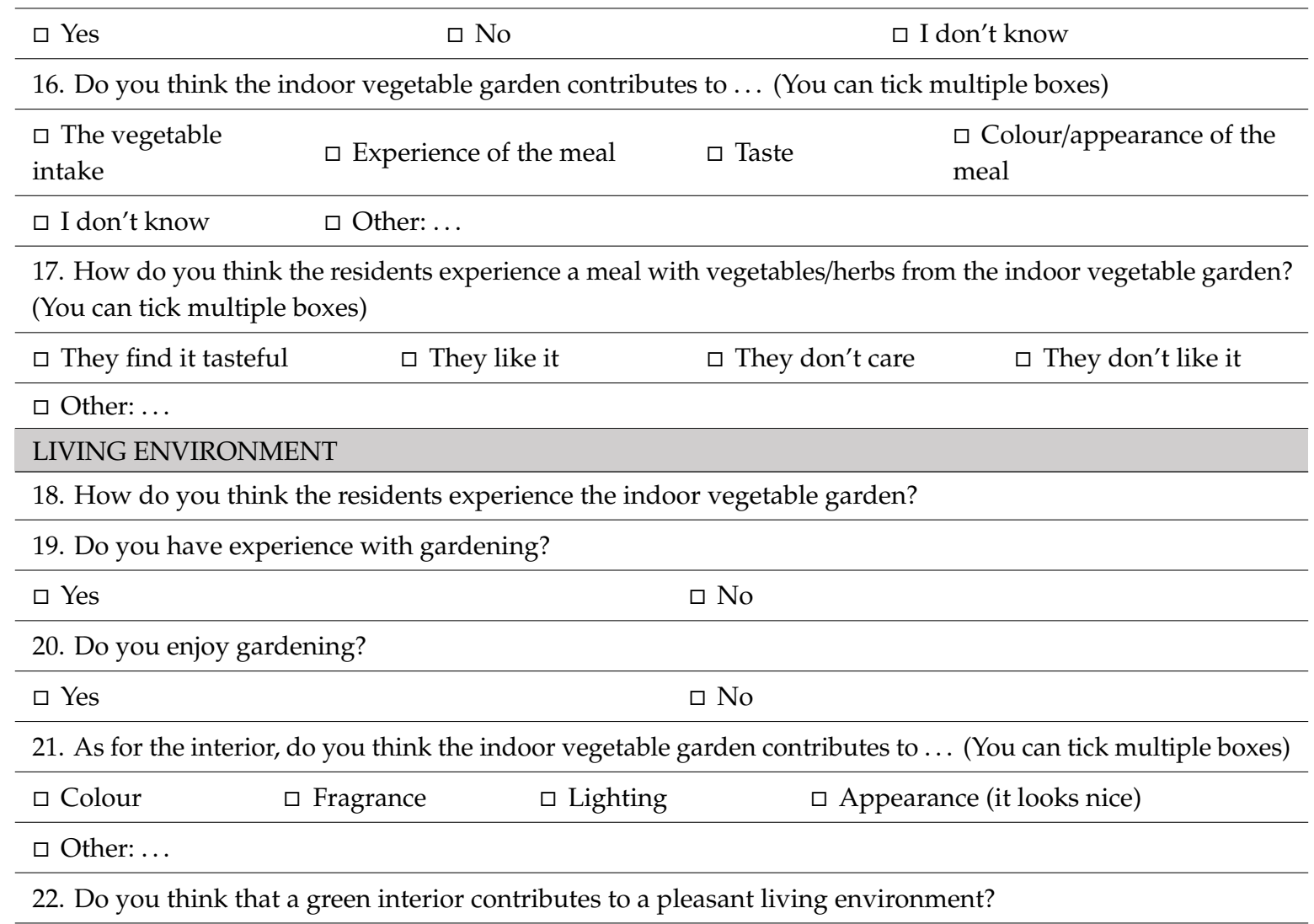

$\square$ Yes, because ...

$\square$ No, because ...

23. Do you think the residents appreciate the indoor vegetable garden? Why or not?

$\square$ Yes, because ...

$\square$ No, because $\ldots$

24. Do the residents enjoy the indoor vegetable garden? (You can tick multiple boxes)

\begin{tabular}{lll}
$\begin{array}{l}\square \text { Yes, they talk } \\
\text { about it }\end{array}$ & $\begin{array}{l}\square \text { Yes, they like } \\
\text { to look at it }\end{array}$ \\
$\square$ I don't know & $\square$ No & $\square$ Other: ... \\
\hline
\end{tabular}

25. Do you have any comments or suggestions about the indoor vegetable garden?

$\square$ Yes, ... 


\section{Appendix C}

Table A1. Demographic characteristics of the survey respondents (data was gathered in the survey).

\begin{tabular}{|c|c|c|c|}
\hline Age & Working Experience (Years) & Role & Location \\
\hline $45-59$ & $>30$ & Service employee & Oosterwolde \\
\hline $45-59$ & $<5$ & Nurse & Oosterwolde \\
\hline $45-59$ & 11 to 20 & Chef & Oosterwolde \\
\hline $35-44$ & 11 to 20 & Nurse, caregiver & Oosterwolde \\
\hline $45-59$ & 21 to 30 & Nurse, caregiver & Oosterwolde \\
\hline$>60$ & 11 to 20 & Caregiver & Biesdel \\
\hline $45-59$ & $>30$ & Food assistant, caregiver, hostess & Biesdel \\
\hline$>60$ & 11 to 20 & Caregiver & Biesdel \\
\hline $45-59$ & 11 to 20 & Service employee & Biesdel \\
\hline $45-59$ & 21 to 30 & Caregiver & Biesdel \\
\hline $45-59$ & 6 to 10 & Nurse, caregiver & t Jagthuis \\
\hline $45-59$ & 11 to 20 & Food assistant, caregiver, hostess & t Jagthuis \\
\hline $20-34$ & 6 to 10 & Nurse, caregiver & $\mathrm{t}$ Jagthuis \\
\hline$>60$ & 11 to 20 & Nurse, caregiver & t Jagthuis \\
\hline $45-59$ & $>30$ & Caregiver & $\mathrm{t}$ Jagthuis \\
\hline $35-44$ & 11 to 20 & Service employee & t Jagthuis \\
\hline $45-59$ & $>30$ & Nurse, caregiver & t Jagthuis \\
\hline $20-34$ & $<5$ & Caregiver, hostess & t Jagthuis \\
\hline $45-59$ & 11 to 20 & Chef & Lorentzhuis \\
\hline $45-59$ & 11 to 20 & Food assistant, hostess & Lorentzhuis \\
\hline $35-44$ & 11 to 20 & Service employee, nurse & Lorentzhuis \\
\hline $35-44$ & 11 to 20 & Service employee & Lorentzhuis \\
\hline
\end{tabular}

\section{References}

1. Statistiek, C.B.v.d. Prognose: 18 Miljoen Inwoners in 2029. Available online: https://www.cbs.nl/nl-nl/nieuws/ 2018/51/prognose-18-miljoen-inwoners-in-2029 (accessed on 31 July 2019).

2. Statistiek, C.B.v.d. Factsheet: Zorggebruik 75-Plussers. 2017. Available online: https://www.cbs.nl/nl-nl/ achtergrond/2017/51/zorggebruik-75-plussers (accessed on 30 July 2019).

3. Sociaal en Culturaal Planbureau. Factsheet Ouderen in Verpleeghuizen En Verzorgingstehuizen. 2017. Available online: https://www.scp.nl/dsresource?objectid=5d941418-16d4-4c1b-a1bf-3d22da78272a\&type=org (accessed on 22 May 2019).

4. Volksgezondheid, M.v.; Sport, W.e. Thuis in Het Verpleeghuis. 2018. Available online: https: //www.rijksoverheid.nl/onderwerpen/verpleeghuizen-en-zorginstellingen/documenten/rapporten/2018/ 04/01/thuis-in-het-verpleeghuis (accessed on 5 June 2019).

5. de Groot, C.P.G.M.; Haveman-Nies, A.; van de Rest, O. Voeding. Bijblijven 2017, 33, 379-390. [CrossRef]

6. Meijers, J.M.M.; Schols, J.M.G.A.; vanBokhorst-de van der Schueren, M.A.E.; Dassen, T.; Janssen, M.A.P.; Halfens, R.J.G. Malnutrition prevalence in The Netherlands: Results of the Annual Dutch National Prevalence Measurement of Care Problems. Br. J. Nutr. 2008, 101, 417-423. [CrossRef] [PubMed]

7. German, L.; Feldblum, I.; Bilenko, N.; Castel, H.; Harman-Boehm, I.; Shahar, D.R. Depressive symptoms and risk for malnutrition among hospitalized elderly people. J. Nutr. Health Aging. 2008, 12, 313-318. [CrossRef] [PubMed] 
8. Meeusen-van Onna, M.; Bouwman, E.; Immink, V.; Sijtsema, S. Kansen Voor Meer Groenten en Fruit in Zorginstellingen; Wageningen Economic Research: Wageningen, The Netherlands, 2016. [CrossRef]

9. van de Vlasakker, P. Indoor Gardens for Nursing Homes. Rural Sociology Wageningen University. Published. 2019. Available online: https://ruralsociologywageningen.nl/2019/06/17/indoor-gardens-for-nursing-homes/ (accessed on 28 September 2019).

10. Al-Shrouf, A. Hydroponics, Aeroponic and Aquaponic as Compared with Conventional Farming. Environ. Sci. Am. Sci. Res. J. Eng. Technol. Sci. 2017, 27, 247-255.

11. Sardare, M.D.; Admane, S.V. A REVIEW ON PLANT WITHOUT SOIL-HYDROPONICS. IJRET 2013, 2, 299-304. [CrossRef]

12. Raji, B.; Tenpierik, M.J.; van den Dobbelsteen, A. The impact of greening systems on building energy performance: A literature review. Renew. Sustain. Energy Rev. 2015, 45, 610-623. [CrossRef]

13. Burchett, M.D. Horticulture Australia, Centre for Environmental Sustainability, Plants and Indoor Environment Quality Group. In Greening the Great Indoors for Human Health and Wellbeing; Horticulture Australia: Sydney, Australia, 2010.

14. Bringslimark, T.; Hartig, T.; Patil, G.G. The psychological benefits of indoor plants: A critical review of the experimental literature. J. Environ. Psychol. 2009, 29, 422-433. [CrossRef]

15. Dijkstra, K.; Pieterse, M.E.; Pruyn, A. Stress-reducing effects of indoor plants in the built healthcare environment: The mediating role of perceived attractiveness. Prev. Med. 2008, 47, 279-283. [CrossRef]

16. Tarran, J.; Torpy, F.; Burchett, M. Use of living pot-plants to cleanse indoor air-research review. In Proceedings of the Sixth International Conference on Indoor Air Quality, Ventilation \& Energy Conservation in Buildings, Sendai, Japan, 28 October 2007; Volume 3, pp. 249-256.

17. Torpy, F.; Zavattaro, M.; Irga, P. Green wall technology for the phytoremediation of indoor air: A system for the reduction of high CO2 concentrations. Air Qual. Atmos. Health 2017, 10, 575-585. [CrossRef]

18. Grijs, Groen E Gelukkig-Plantenwand; IVN Nederland: Amsterdam, The Netherlands, 2017; Available online: https://edepot.wur.nl/426232 (accessed on 8 December 2019).

19. Rappe, E.; Lindén, L. PLANTS IN HEALTH CARE ENVIRONMENTS: EXPERIENCES OF THE NURSING PERSONNEL IN HOMES FOR PEOPLE WITH DEMENTIA. Acta Hortic. 2004, 75-81. [CrossRef]

20. Hosseinifarhangi, M.; Turvani, M.E.; van der Valk, A.; Carsjens, G.J. Technology-Driven Transition in Urban Food Production Practices: A Case Study of Shanghai. Sustainability 2019, 11, 6070. [CrossRef]

21. Haubenhofer, D.K.; Elings, M.; Hassink, J.; Hine, R.E. The Development of Green Care in Western European Countries. EXPLORE 2010, 6, 106-111. [CrossRef] [PubMed]

22. Hartig, T.; Marcus, C.C. Essay: Healing gardens-Places for nature in health care. Lancet 2006, 368, S36-S37. [CrossRef]

23. Söderback, I.; Söderström, M.; Schälander, E. Horticultural therapy: The 'healing garden'and gardening in rehabilitation measures at Danderyd hospital rehabilitation clinic, Sweden. Pediatric Rehabil. 2004, 7, 245-260. [CrossRef]

24. Ulrich, R.S. Health Benefits of Gardens in Hospitals. In Proceedings of the Plants for People, International Exhibition Floriade 2002, Haarlemmermeer, The Netherlands, 20 October 2002.

25. Specht, K.; Weith, T.; Swoboda, K.; Siebert, R. Socially acceptable urban agriculture businesses. Agron Sustain Dev. 2016, 36, 17. [CrossRef]

26. Bourdieu, P. Outline of a Theory of Practice, 1st ed.; Cambridge University Press: Cambridge, UK, 1977. [CrossRef]

27. Bourdieu, P. Practical Reason: On the Theory of Action; Stanford University Press: Stanford, CA, USA, 1998.

28. Bourdieu, P. The Logic of Practice; Reprinted. Stanford Univ. Press: Stanford, CA, USA, 2008.

29. Giddens, A. The Constitution of Society: Outline of the Theory of Structuration; University of California Press: Berkeley, CA, USA, 1984.

30. Røpke, I. Theories of practice-New inspiration for ecological economic studies on consumption. Ecol. Econ. 2009, 68, 2490-2497. [CrossRef]

31. Reckwitz, A. Toward a Theory of Social Practices: A Development in Culturalist Theorizing. Eur. J. Soc. Theory 2002, 5, 243-263. [CrossRef]

32. Schatzki, T.R. Social Practices: A Wittgensteinian Approach to Human Activity and the Social; Cambridge University Press: Cambridge, UK, 1996. 
33. Shove, E.; Pantzar, M.; Watson, M. The Dynamics of Social Practice: Everyday Life and How It Changes; SAGE: Thousand Oaks, CA, USA, 2012. Available online: http://public.ebookcentral.proquest.com/choice/ publicfullrecord.aspx? $\mathrm{p}=880778$ (accessed on 8 May 2020).

34. Shove, E.; Walker, G. Governing transitions in the sustainability of everyday life. Res. Policy 2010, 39, 471-476. [CrossRef]

35. Warde, A. Consumption and Theories of Practice. J. Consum. Cult. 2005, 5, 131-153. [CrossRef]

36. Shove, E.; Pantzar, M. Consumers, Producers and Practices: Understanding the invention and reinvention of Nordic walking. J. Consum. Cult. 2005, 5, 43-64. [CrossRef]

37. Cengiz, B.A.L.; Fikret, E.R.; Sonmez, H. A review of statistical techniques for $2 \times 2$ and RxC categorical data tables in SPSS. J. Pediatric Sci. 2009, 1.

38. Graham, H.; Zidenberg-Cherr, S. California teachers perceive school gardens as an effective nutritional tool to promote healthful eating habits. J. Am. Diet. Assoc. 2005, 105, 1797-1800. [CrossRef] [PubMed]

39. Spees, C.K.; Joseph, A.; Darragh, A.; Lyons, F.; Wolf, K.N. Health behaviors and perceptions of cancer survivors harvesting at an urban garden. Am. J. Health Behav. 2015, 39, 257-266. [CrossRef] [PubMed]

40. Veen, E.J.; Bock, B.B.; Van den Berg, W.; Visser, A.J.; Wiskerke, J.S.C. Community gardening and social cohezion: Different designs, different motivations. Local Environ. 2016, 21, 1271-1287. [CrossRef]

41. Firth, C.; Maye, D.; Pearson, D. Developing "community" in community gardens. Local Environ. Int. J. Justice Sustain. 2011, 16, 555-568. [CrossRef]

42. Farhangi, M.; Turvani, M.E.; Valk AV, D.; Carsjens, G.J. High-Tech Urban Agriculture in Amsterdam: An Actor Network Analysis. Sustainability 2020, 12, 3955. [CrossRef]

(C) 2020 by the authors. Licensee MDPI, Basel, Switzerland. This article is an open access article distributed under the terms and conditions of the Creative Commons Attribution (CC BY) license (http://creativecommons.org/licenses/by/4.0/). 